\title{
PERSONAL PEDAGOGY AS AN ANSWER TO MODERN CHALLENGES OF SOCIETY AND THE WORLD
}

\author{
Yevhen Antypin ${ }^{1}$ \\ Olena Venhlovska ${ }^{2}$
}

DOI: https://doi.org/10.30525/978-9934-26-002-5-2

Pedagogical science has a rich history and a huge heritage done by theorists and practitioners over the years and centuries of research. The study of the history of pedagogy gives modern scientists the opportunity to analyze the mistakes and achievements of previous generations. At the same time, the history, that is revealed to us in pedagogical works, materials from archives, modern scientific research, contains a foundation that allows us to respond effectively to the challenges of current days.

Pedagogy as a science should reveal the patterns of organized activity in the formation of personality. Therefore, in each historical section, the demand for pedagogy will differ according to the demands for personality. Thus, in the history of European pedagogy, we confidently follow the path from the ideas of philosophers of antiquity (education of the mind, self-knowledge, etc.) to the modern search for answers to current questions (distance education, inclusive education, adult education, etc.).

The development of a globalized society has led to a change in the demand for pedagogical science. In contrast to the question «How to prepare a person for life?» at the beginning of the twentieth century, the question «How to teach everyone?» appeared in Ukrainian pedagogical history. The consequence of such a transformation was the development of educational technologies that allowed to teach and educate new generations with high efficiency. At the same time, the accumulation of technology in pedagogical science has led to the loss of such a value as a person.

The current state of pedagogical science gives grounds to assert the need to restore the direction of personal pedagogy based on holistic anthropology. Several empirical and theoretical studies conducted on different samples of students of pedagogical specialties prove the relevance of the personal component in the process of professional and personal training of teachers.

Research of separate psychological components of personal development of future teachers $[2 ; 3 ; 6]$ reveal problems, and therefore the demands that students face during training. The study of self-efficacy as a system-forming factor in the adaptation of first-year students and their primary

\footnotetext{
${ }^{1}$ Borys Grinchenko Kyiv University, Ukraine

${ }^{2}$ Borys Grinchenko Kyiv University, Ukraine
} 
professionalization [3] allows us to assess the impact of the personal dimension of pedagogical activity on the formation of both general and professional competencies of the teacher.

Significant in the context of the development of ideas of personal pedagogy is the study of personal and professional development of future teachers $[1 ; 4 ; 5]$. Scientists present the personal and professional development of students of pedagogical specialties as a real mechanism for creating a modern teacher - ready for life and professional activity in the conditions of accelerated changes and transformations.

In particular, the study «Personal and professional development of future teachers in the process of educational practices» [1] proves the thesis of the need and relevance of the personal dimension of pedagogical activity. The authors of the article, among other things, represent the levels of formation of personal and professional development components: value-personal component, research component, XXI century skills, reflection component. The highest indicator (35\%) in the sample was the value-personal component.

Therefore, we believe that in today's conditions (variability, amount of information, development of technology) it is important to turn to the personal dimensions of pedagogy. An example of this is pedagogical anthropology, which is a productive combination of knowledge about the learner and the educator. Having a person at the center of its study, this science becomes an integrator of pedagogical values.

The accumulated technological experience allows a wide choice among pedagogical tools. But the effectiveness of such a choice will directly depend on a deep understanding of human nature, knowledge of the laws of personality development and awareness of the value of maintaining the natural forces of both children and adults.

\section{References:}

1. Ivaniuk, H., Venhlovska, O., \& Antypin, Ye. (2020). Osobystisno-profesiinyi rozvytok maibutnikh pedahohiv u protsesi navchalnykh praktyk [Personal and professional development of future teachers in the process of educational practices]. Neperervna profesiina osvita: teoriia i praktyka [Continuing professional education: theory and practice], no. 2, pp. 25-34.

2. Melnyk, I. (2020). Problema vyvchennia psykholohichnoho skladnyka zdoroviazberezhuvalnoi kompetentnosti maibutnikh pedahohiv: systemnyi pidkhid [The problem of studying the psychological component of health competence of future teachers: a systematic approach]. Osvitolohichnyi dyskurs: elektronne naukove fakhove vydannia [Educological discourse: Scientific electronic professional edition], no. 2, pp. 221-239.

3. Muzyka, O. (2020). Rozvytok samoefektyvnosti studentiv u protsesi adaptatsiinoho treninhu [Development of students' self-efficacy in the process of 
adaptation training]. Osvitolohichnyi dyskurs: elektronne naukove fakhove vydannia [Educological discourse: Scientific electronic professional edition], no. 2 (29), pp. 132-142.

4. Novyk, I. (2020). «SELF-BOOK» osobystisno-profesiinoho zrostannia maibutnoho pedahoha [ «SELF-BOOK» personal and professional growth of the future teacher]. Osvitolohichnyi dyskurs: elektronne naukove fakhove vydannia [Educological discourse: Scientific electronic professional edition], no. 3 (30), pp. 206-220.

5. Novyk, I., Venhlovska, O., \& Kuzemko, L. (2019). Vykorystannia internetresursiv $\mathrm{v}$ osobystisno-profesiinomu rozvytku maibutnikh pedahohiv [The use of Internet resources in the personal and professional development of future teachers]. Pedahohichni nauky: teoriia, istoriia, innovatsiini tekhnolohii [Pedagogical sciences: theory, history, innovative technologies], no. 4 (88), pp. 3-17.

6. Shepelova, M. (2020). Psykholohichnyi suprovid osobystisno-profesiinoho zrostannia maibutnikh fakhivtsiv doshkilnoi haluzi [Psychological support of personal and professional growth of future professionals in the preschool industry]. Doshkilna osvita $v$ konteksti idei Novoi ukrainskoi shkoly: zbirnyk naukovykh prats [Preschool education in the context of the ideas of the New Ukrainian school: a collection of scientific papers]. Khmelnytsk: FOP Melnyk, pp. 454-464.

\section{STUDENTS’ FOREIGN LANGUAGE SPEECH ACTIVITY AT HIGHER TECHNICAL EDUCATIONAL INSTITUTION}

\section{Kateryna Halatsyn ${ }^{1}$ Olha Yaroshenko ${ }^{2}$}

DOI: https://doi.org/10.30525/978-9934-26-002-5-3

The entry of Ukraine into the pan-European economic and educational space actualize the problem of speech activity in foreign language communication. Foreign language communication becomes an essential component of the future professional activity of a specialist. The relevance of the problem is also determined by the existence of a contradiction between the social order for a highly qualified specialist who speaks a foreign language and can use it in his professional activities and the low level of training of graduates of higher education in a foreign language.

According to researchers, the motivational level is represented by a complex interaction of the aspirations, motives and goals of speech acts as a further result of it. Several internal and external motives stimulate activities.

\footnotetext{
${ }^{1}$ Igor Sikorsky Kyiv Polytechnic Institute, Ukraine

${ }^{2}$ Igor Sikorsky Kyiv Polytechnic Institute, Ukraine
} 